\title{
Possibilities of Using Less Frequently Utilized Areas of Railway Infrastructure
}

\section{Možnosti využití málo frekventovaných oblastí železniční infrastruktury}

\author{
Kristýna Smržová \\ Ústav prostorové tvorby, Fakulta architektury, Vysoké učení technické v Brně \\ školitel: Ing. arch. Barbora Ponešová, Ph.D.
}

\begin{abstract}
This article deals with the legislative, property and financial aspects of railway infrastructure. Many experts says that limiting the network only to its hightraffic-density sections would greatly reduce the cost of maintaining the railways. Financing the infrastructure is one of the biggest disadvantages of rail transportation in contrast to road transportation. What are the possibilities of legislative and property changes in case of less frequently used tracks, and of a possible change of the purpose of use while keeping the track? Could the regions use the new opportunities arising from a change in legislation and use these large unused areas to solve some of the problems of municipalities? Can the potential of railway infrastructure be reused? These possibilities will be explored by the research by design method and through cooperation with economic experts and students. With their help an ideological proposal will be presented to municipal representatives, relevant politicians, etc.
\end{abstract}

KEYWORDS: railways; rail infrastructure; legislation; property relations; railway potential

\footnotetext{
ABSTRAKT: Tento článek se zabývá problematikou legislativní, majetkoprávní a finanční stránky železniční infrastruktury. Mnoho odborníků se shoduje na tom, že omezení sítě jen na úseky s vysokou hustotou dopravy by vedlo k velkému snížení nákladů právě na údržbu železničních tratí, které jsou z hlediska financování tohoto druhu dopravy jedním z největších nevýhod oproti dopravě silniční. Jaké jsou možnosti legislativních a majetkoprávních změn v úsecích málo frekventovaných tratí, či př́ípadná úplná změna účelu využití př̀i současném zachování kolejí? Mohli by např́i-
} 
klad kraje použít nové možnosti plynoucí ze změny právních předpisů a využít tyto rozsáhlé podvyužité plochy pro řešení některých problémů obcí? Lze potenciál železniční infrastruktury nově zužitkovat? Tyto možnosti budou zkoumány metodou research by design a spoluprací s ekonomickými odborníky a studenty, s jejichž pomocí by měl vzniknou ideový návrh, který bude předložen zastupitelům obcí, příslušným politickým orgánům atp.

KLÍČOVÁ SLOVA: železnice; železniční infrastruktura; legislativa; majetkoprávní vztahy; potenciál železnice

\section{Úvod}

Železniční doprava zažila největší rozkvět v 19. století, kdy její extrémní náročnost a nákladnost jejího provozu převyšovaly výhody, které mohla oproti ostatním druhům dopravy poskytnout a to hlavně ohledně množství a hmotnosti převážených nákladů. Není př̌kvapením, že hlavní výsadou železnice byla za průmyslové revoluce přeprava nákladní (uhlí, sůl, průmyslové výrobky, atp.). Od této etapy se požadavky na železniční přepravu proměnily. Na poli osobní i nákladní přepravy vládne automobilová doprava a i objemy a druh převáženého zboží se změnily, obecně se dá říct, že došlo ke zmenšení objemu (i když ne ve všech př́ípadech).

Trendy v zahraničí v této oblasti (Francie, Španělsko, Německo, Japonsko, atp.) jsou zaměřeny hlavně na vysokorychlostní osobní železniční přepravu a nákladní železniční přepravu s kontejnerovými překladišti pro př́padnou finální dojižd’ku kamionem. Tyto druhy zaměření železniční dopravy se vyplatí tehdy, pokud je přeprava obsazena a jsou obsluhovány dostatečné vzdálenosti. Česká republika jako stát s malou rozlohou má $\mathrm{v}$ poměru $\mathrm{k}$ rozloze státu jednu $\mathrm{z}$ nejhustších železničních sítí na světě. Tato hustota je tvořena hlavně tzv. lokálkami - převážně krátkými tratěmi propojujícími menší obce. Tyto tratě nižšího významu vznikaly v letech 1880 - 1910 díky finančním a technickým úlevám tehdy zakotvených v zákonech o místních drahách. Charakterizují je nízké rychlosti (přimknutí dráhy $\mathrm{k}$ terénu, malé poloměry oblouků) a horší zabezpečovací zařízení (Pavlíček 2002). V České republice je proto trend vysokorychlostní železnice možno uplatnit pouze na tzv. páteřní tratě - dráhy propojující větší města a disponující hustotou přepravy, která pokryje i náklady na železniční infrastrukturu - tzv. fixní náklady. Takto by náš stát malý rozlohou, ale s výhodnou geografickou polohou, mohl těžit z napojení případných vysokorychlostních tratí na mezinárodní dopravu. 
Otázkou tedy zůstává, co se stane s lokálními tratěmi a odstavnými kolejemi nádraží a dep, které kvůli menšímu objemu dopravy chátrají, ale zároveň představují obrovské plochy cenných pozemků nezřídka v těsné blízkosti center obcí. Tento problém se logicky dotýká i starých výrobních areálů a dalších brownfieldů, které jsou na železnici ze zištných důvodů časů minulých napojeny. Problematika těchto lokalit je předmětem výzkumu.

\section{Železniční infrastruktura a majetkoprávní vztahy}

Český železniční systém tvoří zhruba 9463 km tratí, z nichž je 2596 km zařazeno do transevropského železničního systému, regionálních tratí je $4553 \mathrm{~km}$. A nejde jen o kolejové těleso. Součástí infrastruktury je množství budov a dopravních staveb (mosty, tunely, atp) (SŽDC 2018).

Základní legislativní změnou, která proběhla na českých železnicích v tomto dvacetiletí, bylo v souladu se směrnicemi Evropské unie oddělení provozovatele dopravních služeb od vlastníka železniční cesty. Cílem bylo odstranění monopolu jednoho dopravce a zavedení konkurence spolu s nuceným tlakem na vyšší kvalitu služeb, který volná konkurence přináší. Od Českých drah (ČD) byla proto v roce 2003 oddělena Správa železniční dopravní cesty (SŽDC) a uvedený předpoklad o pozitivní konkurenci funguje jen částečně, protože ČD stále zůstávají dominantním dopravcem (Tomeš 2006). Nicméně tento fakt se v následujících letech změní, protože v roce 2023 skončí dle Evropské komise možnost zadávání smluv jednomu dopravci bez soutěže a v roce 2019 skončí desetileté smlouvy ČD s ministerstvem dopravy týkající se většiny spojů (Sůra 2017) a železnice je prakticky závislá na vnějších dotacích od státu, potažmo EU.

SŽDC jako vlastník železniční infrastruktury zodpovídá za její bezpečnost a na její bedra tak padají rozsáhlé investice spojené s fixními náklady na kolejovou strukturu. Logicky pokud některé tratě nejsou přiměřeně využívány, snaží se jich zbavit a vyřadit je tak z rozsáhlé struktury jí spravované sítě nebo je aspoň pronajmout. Pod tyto dráhy spadají ve velké míře i lokálky a vlečky.

SŽDC je vlastníkem rozsáhlé sítě spojující města, situace je ale poněkud jiná, pokud hledáme majitele většiny nádraží a přilehlých kolejových struktur v obcích, tím jsou ČD. ČD dnes z podobných důvodů jako SŽDC regulují počet svých pozemků. Nejviditelnějším př́kladem je v této souvislosti současná kauza rušení dep a jejich přednostů (hlavně zánik pěti dep v Plzni, Praze, Brně, Olomouci a České Třebové) (Šindelář 2018). Vlastníků drážních pozemků je samozřejmě více, ale žádný z nich nedisponuje, tak značným rozsahem pozemků jako dva výše zmiňované subjekty. 


\section{Přínos zachování železniční struktury}

Bylo již zmíněno, že předmět výzkumné otázky se týká hlavně tratí a železničních struktur, které jsou částečně nebo úplně nevyužité. Jelikož tyto pozemky jsou často předmětem prodeje ze strany SŽDC nebo ČD, slušelo by těmto strukturám prozkoumání jiných možností využití, které by ale zároveň nemuselo nutně znamenat zbavování se kolejového tělesa a železničních technologií, jak tomu v současnosti v mnoha př́padech je.

„Ořezávání” (myšleno rozprodávání) železniční struktury probíhá prozatím organicky a chaoticky. Jde vlastně nejčastěji o vyjmutí pozemku/budovy z této rozsáhlé struktury a jeho/její začlenění do okolí, např. vytvoření rodinného domu. Dalším př́ikladem může být odkoupení zchátralé regionální tratě obcí, která kolejové těleso rozebere a vytvoří místo něj cyklostezku, protože pro trat byla příhodně vytyčena rovina. Uvedené prŕílady využijí potenciál již vystavěné struktury jen omezeně.

Musíme si nejdříve uvědomit souvislosti. Železniční struktura, navzdory zdánlivé subtilnosti kolejového tělesa, fatálně zasáhla do tvorby krajiny a urbanismu jak ho známe dnes. V podstatě dodnes bydlíme ve městech, která $\mathrm{z}$ velké části definovala železnice na základě dostupnosti průmyslových areálů a nádraží a souvisejících příjezdových podmínek (at̉ už z hlediska přepravy nákladu nebo osob). Automobilová doprava v podstatě neexistovala a železniční doprava zprvu nebyla vhodná pro provoz ve městě a proto byla města plánována s jinými nároky na dopravu, než jaké známe dnes. Navzdory tomu, že železnice masivně ovlivnila krajinu, je považována za druh dopravy, který je environmentálně jedním z nejvýhodnějších.

Dalším zajímavým aspektem jsou podmínky vytvořené pro tento druh dopravy. Tratě a nádražní plochy byly pečlivě plánovány, protože železnice nesnese velké terénní sklony, musí být stavěna pro vysokou zátěž a poloměry oblouků musí být dostatečně široké, aby vlak mohl dosáhnout vyšší rychlosti. Mosty a tunely jsou stavby, které jsou ekonomicky a technologicky náročné a proto se $\mathrm{k}$ jejich výstavbě přistupovalo jen $s$ velkým uvážením. Plochy nádraží jsou velmi dobře dostupné, rozsáhlé, s nepatrnými terénními sklony a často se nachází v lukrativních částech obcí. Všechny tyto faktory vytváří určitý potenciál, který vznikl spolu se železnicí a tento výzkum si klade za úkol zjistit, zda je možné jej využít v souvislosti, která by zachovala či možná přetlumočila do dnešních požadavků původní účel věci. V tomto spatřuji možný vklad architektonického vzdělání do jinak ryze technické záležitosti, protože je možné spatřit problematiku v jiných, širších souvislostech než jen přepravně - technických.

Oblast výzkumu se bude týkat zároveň i prozkoumání nových možností při př́ípad- 
ném vyjímání tratí/ struktur z železniční dopravní sítě, protože tyto struktury zároveň pozbydou řadu omezení a legislativních opatření, které souvisí s provozováním dráhy. Jaký by mohl být př́nos zachování kolejového tělesa a železniční struktury v jiných souvislostech než jen přepravních? Jak by mohla např́iklad městská část těžit z toho, že půlku rozlohy jejího katastru zaujímá staré nákladní nádraží? Otázky tohoto typu jsou samozřejmě př́liš obecné, protože i přes racionální uspořádání železniční struktury a podobnost situací v ní, nelze učinit důvěryhodný závěr bez prozkoumání konkrétního místa a jeho souvislostí.

\section{Metoda výzkumu}

Z důvodů komplexnosti a složitosti majetkoprávních vztahů, legislativy a rozmanitosti různorodých podmínek $\mathrm{v}$ tomto dopravním odvětví je náročné předvídat možnosti či vybrat směr výzkumu. $\mathrm{V}$ současnosti neexistuje mechanismus, který by se touto problematikou seriózně a prakticky zabýval. Možný potenciál železniční struktury tak může být bez probádání jednoduše promarněn. Právě proto volím metodu research by design. Výzkum je zaměřen na reálné př́klady v reálném prostředí, na kterých je demonstrováno a prakticky vyzkoušeno, jak konkrétně lze alternativně využít železnici a co je v daném př́ípadě třeba udělat. Problémy se týkají majetkoprávních vztahů, bezpečnosti, legislativy, grantové politiky, PR, atp. Tato metoda empiricky prověří danou situaci a může tak přinést fakta. Metoda research by design je dnes uznávána jako plnohodnotná metoda výzkumu na předních univerzitách a funguje jako kreativní protipól k vědeckému výzkumu, který přináší analytické podklady. Výzkum bude cílit na výběr lokalit se zaměřením na nevyužívané plochy nádraží, dep a odstavných kolejových ploch. Součástí bude práce se studenty formou ateliérové výuky, workshopů nebo letní školy.

\section{Seznam literatury}

PAVLÍČEK, Stanislav. Naše lokálky: místní dráhy v Čechách, na Moravě a ve Slezsku. Praha: Dokořán, 2002. ISBN 80-865-6913-6.

SŽDC, 2012. Železnice ČR. sždc [online]. [Cit. 8.7.2018]. Dostupné z: http://www. szdc.cz/o-nas/zeleznice-cr.html

TOMEŠ, Zdeněk. Konkurence na železnici. Národohospodářský obzor, 2006: ESF MU Brno, 2006, roč. 2006, č. 4, s. 96-102. ISSN 1213-2446. 
SŮRA, Jan. Konec monopolu Českých drah. Začne boj o dotačních třináct miliard. ekonomika idnes [online]. [Cit. 8.7.2018]. Dostupné z: https://ekonomika.idnes.cz/dotace-zeleznice-ceske-drahy-miliardy-d8v-/eko-doprava.aspx?c=A170328_2315242_eko-doprava_rts

Šindelář, Jan. Dráhy se mění. Po dvaceti letech zruší depa i přednosty. zdopravy [online]. [Cit. 8.7.2018]. Dostupné z: https://zdopravy.cz/drahy-se-meni-po-dvaceti-letech-zrusi-depa-i-prednosty-7313/

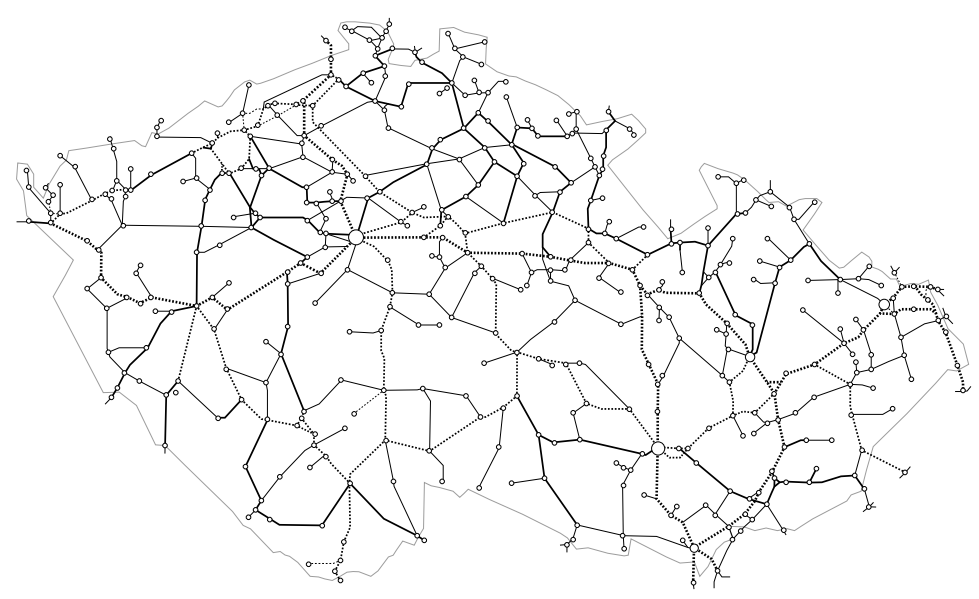

Obr. 1. Česká železniční sít (zdroj: vlastní obr.) 